\title{
PENGGUNAAN MEDIA LCD PROYEKTOR DENGAN PENDEKATAN SAINTIFIK UNTUK MENINGKATKAN PEMAHAMAN TEKS BERITA DALAM PEMBELAJARAN BAHASA INDONESIA \\ (PTK Bahasa Indonesia pada Siswa Kelas VIII-I di SMP Negeri 2 Jatinunggal Tahun 2018)
}

\author{
Oleh: \\ Yayah Rokayah \\ Guru SMP Negeri 2 Jatinunggal Sumedang \\ Email: takarir@ rocketmail.com
}

\begin{abstract}
ABSTRAK
Permasalahan yang mengemuka di SMP Negeri 2 Jatinunggal diantaranya rendahnya prestasi belajar siswa. Melalui pembelajaran Bahasa Indonesia menggunakan LCD Proyektor dengan Pendekatan Saintifik", permasalahan ini dicoba untuk dilakukan penelitian tindakan kelas. Materi yang dipelajari adalah teks berita, yang merupakan hasil pengalaman mengajar pada siswa Kelas VIII-I semester gasal tahun pelajaran 2018/2019. Hasil pembelajaran pada akhir Siklus ke-1, penilaian pengetahuan rata-ratanya mencapai 70 , keterampilan mencapai 72 , dan sikap baik. Selain itu siswa diminta memberi komentar tentang pembelajaran yang telah dilakukan dengan menggunakan angket, diketahui sebagian besar siswa (76\%) menyatakan senang mengikuti pembelajaran dengan model yang telah dilakukan. Pada akhir Siklus ke-2, penilaian pengetahuan rata-ratanya mencapai 86 , keterampilan mencapai 82 , dan sikap amat baik, serta hampir semua siswa $(98,6 \%)$ menyatakan senang mengikuti pembelajaran kreatif ini. Bahkan beberapa siswa mengusulkan agar pembelajaran ke depan seperti yang telah dilakukan selama ini.
\end{abstract}

Kata Kunci: Media LCD Proyektor, Pendekatan Saintifik, dan Teks Berita

\section{PENDAHULUAN}

Perkembangan media teknologi dalam dunia pendidikan selalu berkembang dari tahun ke tahun. Kalau 20 tahun kebelakang hampir setiap sekolah dalam proses belajar mengajar dalam ruang kelas, guru menggunakan media tradisional, yaitu menggunakan kapur dan papan tulis hitam. Media sederhana sejak lama sudah digunakan sebagai sarana komusikasi. Ketika orang-oarang masih hidup dalam gua-gua, pahat, pasir, paku, pisau dari batu, busur dan anak panah telah digunakan untuk mengerjakan keterampilan dengan fungsi atau kegunaan peralatan tersebut (Gafur, 2004: 2).

Kondisi saat ini, media yang merupakan salah satu produk teknologi memegang peranan penting dalam membantu tercapainya proses belajar mengajar. Kegiatan belajar mengajar saat ini bergerak maju kedepan, kegiatan ceramah, dan berpindah kearah menggunakan banyak media.

Berkembangnya ilmu pendidikan saat ini menandakan bahwa pembelajaran terkini harus bersifat transfaran dengan maksud agar semua murid dapat mengerti dan memahami materi yang diajarkan. Karena itu di perlukan suatu media pembelajaran yang membantu para pengajar (guru) menyampaikan suatu materi.
Pendidikan yang makin lama terus berkembang menuntut terciptanya suatu media yang dapat memperjelas materi yang disampaikan pengajar. Apabila kegiatan belajar-mengajar tidak memilki tek nik baru dalam pelaksanaannya, dikhawatirkan para murid akan sampai pada titik jenuhnya dan menyebabkan murid tidak mengerti materi yang diberikan.

Sekarang telah tercipta media pembelajaran yang dapat meningkatkan kualitas belajar yaitu LCD Proyektor yang dapat menampilkan materi dari bidang apapun dengan cara yang lebih menarik dan sangat inovatif. Proyektor LCD merupakan salah satu jenis proyektor yang digunakan untuk menampilkan video, gambar, atau data dari komputer pada sebuah layar atau sesuatu dengan permukaan datar seperti tembok, dan sebaainya.

Selain perkembangan teknoloi seperti itu, sekarang tea terjadi perkebangan kurikulum dengan adanya Kurikulum 2013. Salah satu pendekatan yang diamanatkan pada kurikulm tersebut yaitu pendekatan saintifik Pendekatan saintifik lahir dengan mengadaptasi scientific learning. Istilah scientific learning diindonesiakan menjadi pembelajaran saintifik, atau disebut juga pembelajaran ilmiah. Dalam pengertian ini, pendekatan saintifik mempunyai ciri penanda 
sebagai proses pembelajaran yang dapat dipadankan dengan suatu proses penemuan secara ilmiah. pembelajaran saintifik ini juga terlahir karena adanya kurikulum 2013. Kurikulum 2013 atau biasa yang disebut dengan $\mathrm{K}-13$ ini lebih mengacu pada pengamatan esensi pendekatan saintifik.

Pendekatan saintifik diyakini sebagai titian emas perkembangan dan pengembangan sikap, keterampilan, dan pengetahuan siswa.Pendekatan saintifik merujuk pada teknikteknik investigasi atas suatu atau beberapa fenomena atau gejala, memperoleh pengetahuan baru, atau mengkoreksi dan memadukan pengetahuan sebelumnya.Untuk dapat disebut ilmiah, metode pencarian (method of inquiry) harus berbasis pada bukti-bukti dari objek yang didapat dari pengamatan, empiris, dan terukur dengan prinsip-prinsip pengamatan yang spesifik.

Pendekatan saintifik ini dinilai lebih efektif karena mengajak peserta didik untuk berpikir secara ilmiah. Pembelajaran ditekankan kepada pendekatan saintifik yang terlembaga kepada lima proses yaitu mengamati, menanya, eksperimen/mengumpulkan informasi, menalar/ menganalisis, serta membuat jejaring/mengkomunikasi. Dalam lima proses tersebut, setiap siswa dituntut agar mampu menerapkan sikap ilmiah seperti jujur, objektif, dan akuntabel selama proses pembelajaran.

Dari kedua jenis perkembangan itu akan digunakan penulis sebagai bahan peleitian tindakan kelas. Hal ini dikarenakan daata taun sebelumnya hasil penilaianpembelejaran tentan teks berita kurang memenuhi KKM secara klasikal. Penelitian ini dilakasanakan pada Siswa Kelas VIII-I pada Tahun Pelajaran 2018/2019 Semester 1.

\section{METODE PENELITIAN}

Penelitian dilaksanakan di SMP Negeri 2 Jatinunggal sebagai tempat unit kerja peneliti. Penelitian dilaksanakan pada jam mengajar pada siswa di kelas VIII-I sebagai kelas yang digunakan dalam penelitian ini, dengan keadaan siswanya berjumlah 32 peserta didik. Waktu yang digunakan untuk penelitin ini sesuai dengan jadwal pelajaran, yang terdapat di kelas VIII-I. Pelaksanaan dari tanggal 1 Agustus sampai dengan 3 Oktober 2018.

Pada penelitian ini, tingkat keberhasilannya diambil dari data penilian. Penilaian merupakan suatu upaya untuk mengumpulkan berbagai data yang diharapkan memberi gam- baran perkembangan belajar siswa. Data yang dikumpulkan bukan mencari informasi tentang belajar siswa, akan tetapi data yang dikumpulkan harus diperoleh dari kegiatan nyata yang dikerjakan siswa pada saat melakukan proses pembelajaran.

Dalam pembelajaran Bahasa Indonesia, setidaknya ada tiga aspek yang dievaluasi yaitu aspek pengetahuan (kognitif), keterampilan dan sikap (spiritual dan sosial). Pemahaman aspek pengetahuan diukur menggunakan tes tertulis pada akhir setiap siklus penelitian berupa ulangan harian, aspek keterampilan diukur menggunakan tes praktik dan pengamatan. Sedangkan sikap spiritual dan sosial diamati pada saat siswa melakukan pembelajaran.

Penilitian ini dilaksanakan dengan 2 (dua) siklus, yang terdiri dari:

\section{Siklus Pertama}

Siklus ini terdiri dari :

\section{a. Perencanaan (Planning)}

Sebelum melakukan penelitian, peneliti mempersiapkan hal-hal sebagai berikut:

1) Mengidentifikasikan bahan- bahan dan media pembelajaran

2) Menyusun silabus dan RPP tentang teks berita

3) Menyiapkan alat bantu pembelajaran

4) Menyiapkan lembar tes teks berita

5) Menyiapkan lembar observasi.

\section{b. Tindakan atau Pelaksanaan (Acting)}

Tindakan pada Siklus I terdiri dari 2 pertemuan. Setiap pertemuannya 2 jam pelajaran. Kegiatan pembelajaran, yang meliputi:

1) Pendahuluan

$>$ Guru membuka kegiatan pembelajaran dengan berdoa. (PPK)

$>$ Guru menanyakan ketidakhadiran siswa.

$>$ Guru menyampaikan KD, indikator, dan tujuan pembelajaran yang akan dilakukan.

$>$ Guru dan siswa menyepakati langkah-langkah kegiatan yang akan dilaksanakan untuk mencapai kompetensi.

$>$ Guru memberikan soal pre-tes

2) Keiatan Inti

$>$ Guru menanyangkan judul sebuah berita.

D Siswa menuliskan prediksi isi berita berdasarkan judul tersebut. (literasi) 
Guru menayangkan video berita yang disampaikan oleh pembawa berita.

> Siswa menemukan isi berita yang ditayangkan.

> Siswa menemukan struktur berita yang ditayangkan.

$>$ Guru menyampaikan keterkaitan tayangan berita dengan materi yang akan diajarkan.

$>$ Siswa dibagi menjadi beberapa kelompok yang terdiri dari dua orang.

$>$ Guru memberikan sebuah teks berita ke tiap kelompok.

$>$ Siswa mengamati teks berita. (literasi)

$>$ Dengan dipandu guru, setiap kelompok menemukan isi berita berdasarkan struktur teks berita (HOTS)

$>$ Siswa menuliskan unsur kebahasaan teks berita

> Siswa mempresentasikan hasil kerja diskusi kelompok di depan kelas. (4C)

$>$ Siswa lain diberi kesempatan untuk

3) Penutup menyampaiakan tanggapan.

$>$ Guru memberi penguatan terkait dengan materi yang telah dipelajari.

$>$ Siswa dibantu oleh guru menyimpulkan hasil pembelajaran yang telah berlangsung.

> Siswa menerima tugas dari guru untuk menemukan informasi teks berita berdasarkan struktur berita.

> Siswa merefleksi PBM yang berlangsung.

$>$ Guru beserta siswa mengakhiri kegiatan belajar mengajar dengan mengucap syukur kehadirat Tuhan Yang Maha Esa.

\section{c. Observasi (Observing)}

Pada tahap observasi peneliti melakukan pengamatan selama kegiatan berlangsung, untuk perbaikan siklus selanjutnya. peneliti juga meminta bantuan teman guru untuk mengamati kegiatan proses pembelajaran berlangsung dengan menggunakan lembar observasi aktifitas guru dan lembar keaktifan siswa.

\section{d. Refleksi}

Tahap ini merupakan tahap menganalisa, mensintesa, hasil dari catatan selama kegiatan proses pembelajaran menggunakan instrumen lembar pengamatan dan tes. Dalam refleksi melibatkan siswa, teman sejawat yang mengamati dan kepala sekolah. Untuk melakukan perencanaan pada siklus berikutnya, peneliti mengidentifikasi dan mengelompokkan masalah yang timbul pada pembelajaran siklus I.

\section{Siklus Kedua}

Siklus ini berupa

\section{a. Perencanaan (Planning)}

Sebelum melakukan penelitian, pene-

liti mempersiapkan hal-hal sebagai berikut :

1) Mempertimbangan hasil refleksi pada siklus pertama

2) Mengidentifikasikan bahan pembelajaran

3) Menyusun silabus dan RPP tentang pengaruh kalor

4) Menyiapkan alat bantu pembelajaran

5) Menyiapkan lembar tes pengaruh kalor

6) Menyiapkan lembar observasi

b. Tindakan atau Pelaksanaan (Acting) meliputi:

Berupa kegiatan pembelajaran, yang

1) Pendahuluan

$>$ Guru membuka kegiatan pembelajaran dengan mengucapkan salam.

$>$ Guru menanyakan ketidakhadiran siswa.

$>$ Guru menyampaikan tujuan pembelajaran.

$>$ Guru memberikan motivasi kepada siswa.

$>$ Guru menyampaikan langkahlangkah kegiatan yang akan dilaksanakan untuk mencapai kompetensi

2) Kegiatan Inti

$>$ Siswa dibagi menjadi beberapa kelompok yang terdiri atas empat orang.

> Siswa dalam kelompok menyimak sebuah berita di $\mathrm{TV}$, radio, atau sumber lain.

> Masing-masing kelompok mencari informasi atau berdiskusi untuk menyimpulkan isi teks berita $(5 \mathrm{~W}+1 \mathrm{H})$.

$>$ Siswa menuliskan teks berita hasil diskusi kelompoknya berdasarkan $5 \mathrm{~W}+1 \mathrm{H}$

Siswa mempresentasikan teks berita hasil diskusi kelompok di depan kelas. 
Siswa lain diberi kesempatan untuk menyampaikan tanggapan tentang teks berita.

Setiap siswa melakukan proses penyuntingan (pengoreksian) atas teks berita yang dibuat teman. Materi penyuntingan meliputi struktur teks berita, unsur kebahasaan, pengakalimatan, ejaan dan tanda baca.

> Berdasarkan hasil penyuntingan teman, siswa melakukan perbaikan dan melakukan penulisan teks berita sampai final.

3) Penutup

a) Mengadakan evaluasi berupa pertanyaan secara lisan kepada siswa sesuai dengan tujuan pembelajaran khusus.

b) Memberi penghargaan kepada siswa atau kelompok yang bekerja dengan baik dan benar.

c) Membimbing siswa membuat rangkuman pelajaran.

d) Memberi tugas di rumah.

\section{c. Pengamatan (observing)}

Kegiatan ini yaitu mengamati proses pembelajaran dan menilai hasil tes serta hasil praktek sehingga diketahui hasilnya.

\section{d. Refleksi (reflecting)}

yaitu menyimpulkan pelaksanaan hasil tindakan pada siklus II.

\section{HASIL PENELITIAN DAN \\ PEMBAHASAN \\ Deskripsi Setting Penelitian}

Pelaksanaan kegiatan penelitian tindakan kelas di Kelas VIII-B SMP Negeri 2 Jatinunggal Kabupaten Sumedang Jawa Barat. Jumlah siswa 32 orang, Agar memudahkan dalam pengamatan aktivitas siswa dan penilaiannya, maka keadaan siswa itu dibagi kedalam 8 kelompok dan setiap kelompoknya yang heterogen dengan memperhatikan tingkat kemampuan belajar, dan masalah gender.

\section{Deskripsi Hasil Siklus I}

Pada siklus 1 ini telah dilaksanakan kegiatan yang terdiri dari perencanaan, pelaksanaan, pengamatan, dan refleksi.

\section{a. Perencanaan}

Sebelum dilaksakan penelitian menyiapkan siswa Kelas KELAS VIII-I sebagai objek dan subjek penelitian, menyiapkan instrumen observasi, menentukan observer, menentukan guru model dalam hal ini peneliti, RPP, LKS, dan berbagai alat serta bahan yang diperlukan untuk kegiatan pembelajaran dan tindakan pada Siklus 1 ini.

\section{b. Pelaksanaan Tindakan}

Pelaksanaan ini berupa implementasi dengan melaksanakan kegiatan pembelajaran di Kelas VIII-I dengan guru modelnya adalah peneliti dan penulis. Dari hasil kegiatan ini siswa memperloeh pemahaman tentang teks berita.

\section{c. Pengamatan}

Dari kegiatan ini diperoleh hasil belajar menunjukkan bahwa dari 32 peserta didik yang mengikuti tes hasil belajar dengan KKM 67, aspek pengetahuan terdapat ketuntansan belajar mencapai $34,38 \%$ dan rata-ratanya 58,81 .

Sedangkan aspek keterampilan, hasilnya menunjukkan bahwa dari 32 peserta didik yang mengikuti penilaian keterampilan dengan KKM 67, terdapat ketuntansan belajar mencapai $56,25 \%$ dan rata-ratanya 66,09 .

Pada aspek sikap, hasilnya tampak menunjukkan bahwa dari 32 peserta didik, nilai sikapnya yang memenuhi KKM B, mencapai $78 \%$.

\section{d. Refleksi}

Para observer, pada umumnya menyatakan bahwa siswa kurang begitu perhatian ketika guru melaksanakan pembelajaran sehingga perlu ada perbaikan dalam model dan media pembelajarannya. Maka penelitian perlu dilanjutkan ke Siklus II.

\section{Deskripsi Hasil Siklus II}

Pada siklus 2 ini telah dilaksanakan kegiatan yang terdiri dari perencanaan, pelaksanaan, pengamatan, dan refleksi.

\section{a. Perencanaan}

Setelah ada masukkan, saran, dan komentar dari para observer, diadakan kegiatan perencanaan. Pada perencanan ini sangat memperhatikan hasil refleksi dari siklus 1, agar siswa lebih aktif dan berani dalam bekerja kelompok, diskusi kelas, dan menjawab pertanyaan, dan terampil dalam menentukan kalor jenis suatu zat padat. Pembuatan RPP, LKS, dan berbagai alat serta bahan yang diperlukan untuk kegiatan pembelajaran dan tindakan pada siklus 2 ini dikerjakan oleh peneliti besama-sama dengan guru lainnya.

\section{b. Pelaksanaan Tindakan}

Pelaksanaan tindakan ini, yaitu pelaksanaan pembelajaran yang disajikan oleh peneliti sebagai guru modelnya. Adapun pelaksanaan kegiatan ini terdiri dari kegiatan yang sesuai 
dengan RPP menentukan struktur teks berita dan unsur kebahasaan teks berita.

\section{c. Pengamatan}

Pada siklus kedua ini, para observer dan peneliti mengamati kegiatan menentukan struktur teks berita dan unsur kebahasaan teks berita. Adapun hasil pembelajarannya menunjukkan bahwa dari 32 peserta didik yang mengikuti tes hasil belajar dengan KKM 67, aspek pengetahuan terdapat ketuntansan belajar mencapai $87,5 \%$ dan rata-ratanya 76,31.

Sedangkan aspek keterampilan, hasilnya menunjukkan bahwa dari 32 peserta didik yang mengikuti penilaian keterampilan dengan KKM 67, terdapat ketuntansan belajar mencapai $94 \%$ dan rata-ratanya 75,78 .

Pada aspek sikap, hasilnya tampak menunjukkan bahwa dari 32 peserta didik, nilai sikapnya yang memenuhi KKM B, mencapai 94\%.

\section{d. Refleksi}

Setelah selesai pelaksanaan pembelajaran atau implementasi, pada siklus 2 ini telah terjadi peningkatan hasil penilaian, tidak perlu dilakukan ke siklus berikutnya. Sehingga dengan menggunakan media LCD Proyektor dengan Pendekatan Saintifik dapat meningkatkan pemahaman siswa pada meteri teks berita pembelajaran Bahasa Indonesia.

\section{Pembahasan}

Dari kegiatan pembelajaran pada penelitian ini menunjukkan ada perubahan kemampuan pada aspek pengetahuan, keterampilan, dan sikap.

\section{Adanya peningkatan hasil belajar pada aspek pengetahuan}

Dari keiatan penelitian ini menunjukkan bahwa dari 32 peserta didik yang mengikuti proses pembelajaran yang menggunakan media LCD Proyektor dengan Pendekatan Saintifik dengan KKM 67, tampak menunjukkan bahwa ada peningkatan pemahaman tentang teks berita, baik secara individu maupun klasikal. Pada aspek pengetahuan ini terdapat peningkatan ketuntansan belajar sebesar 53,12\% dari 34,38\% menjadi $87,5 \%$. mencapai $37,5 \%$ dan rataratanya 61,13 .

\section{Adanya peningkatan hasil belajar pada aspek keterampilan}

Sedangkan aspek keterampilan, hasilnya tampak menunjukkan bahwa terdapat kenaikan dalam aspek keterampilan, yaitu kenaikan ketuntansan belajar mencapai 38\% dari 56\% pada Siklus I menjadi $94 \%$ pada Siklus II.
Sedangkan rata-ratanya ada kenaikan sebesar 9,69, dari 66,09 pada Siklus I menjadi 75,78 pada Siklus II.

\section{Adanya peningkatan hasil belajar pada aspek sikap}

Pada aspek sikap, hasilnya tampak menunjukkan bahwa dari 32 peserta didik, nilai sikapnya yang memenuhi KKM B, ada kenaikan $16 \%$ dari $78 \%$ pada Siklus I menjadi $94 \%$ pada Siklus II

\section{PENUTUP}

Secara umum dari hasil pengamatan dan tes sebelum pra siklus, hingga Siklus II dapat disimpulkan bahwa melalui penggunaan media LCD proyektor dengan pendekatan saintifik dapat meningkatkan pemahaman teks berita dalam pembelajaran Bahasa Indonesia, yaitu:

1. Dapat meningkatan hasil belajar pada aspek pengetahuan

Hasil penelitian ini dapat dicermat pada Grafik 1 berikut :

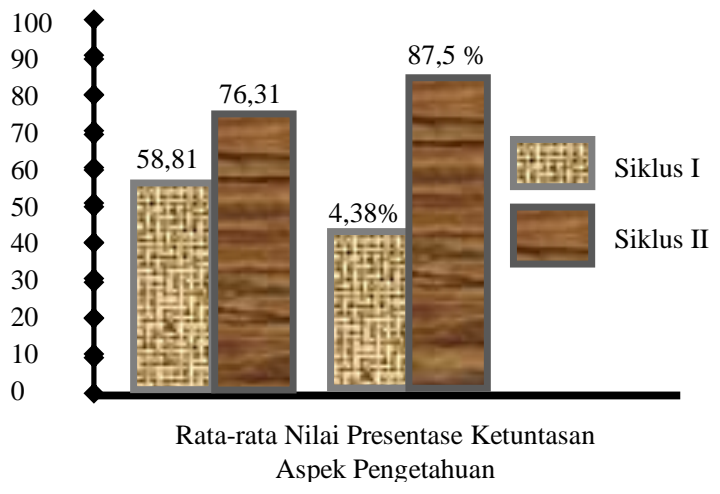

Grafik 1 Rata-rata Nilai Proses dan Presentase Ketuntasannya Aspek Pengetahuan pada Siklus I dan II

2. Dapat meningkatan hasil belajar pada aspek keterampilan

Hasil penelitian ini dapat dicermat pada Grafik 2 berikut

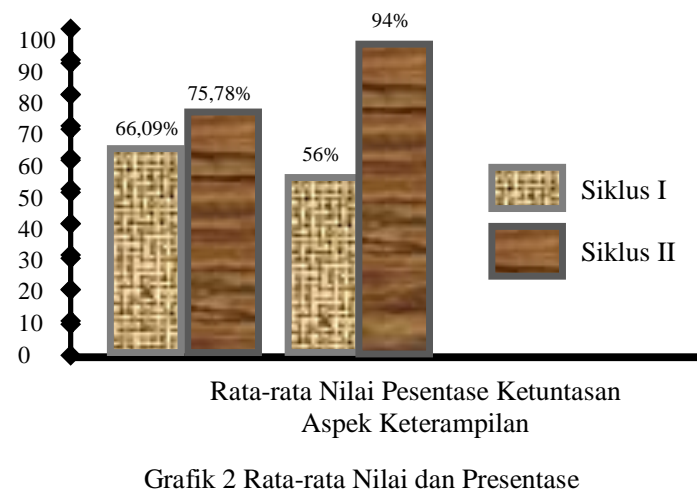

Ketuntasannya Aspek Keterampilan pada Siklus I dan II 
3. Dapat meningkatan hasil belajar pada aspek sikap

Hasil penelitian ini dapat dicermat pada Grafik 3 berikut

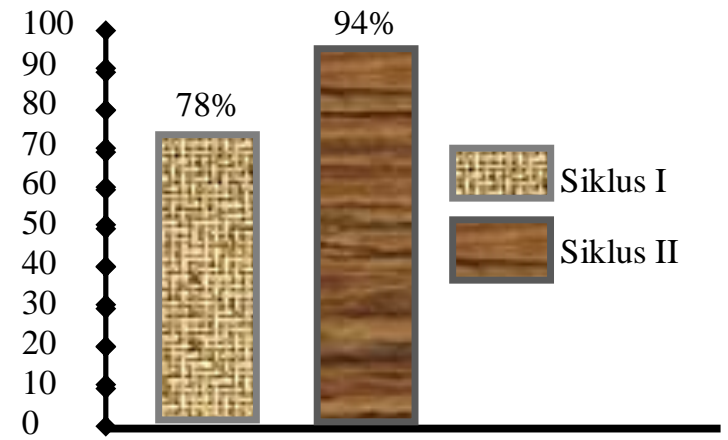

Presentase Ketuntasan Aspek Sikap

Grafik 3 Presentase Ketuntasannya Aspek

Sikap pada Siklus I dan II

Ada beberapa saran dari kegiatan penelitian ini, diantaranya:

1. Penyajian pembelajaran ini memang membutuhkan cukup banyak alat pendukung, oleh karena itu dalam pengadaannya dapat melibatkan siswa.

2. Sebelum pembelajaran, guru harus mengecek peralatan yang dipakai sekaligus mencobanya terlebih dahulu.

3. Sebelum pembelajaran berlangsung, siswa perlu mendapat petunjuk seperlunya menyangkut $5 \mathrm{M}$ pada pembelajaran siantifik.

\section{DAFTAR PUSTAKA}

Arikunto, Suharsimi. 2013. Prosedur Penelitian Suatu Pendekatan Praktik. Jakarta: PT. Rineka Cipta.

Abdul Gafur Daniamiseno. 2004. Peranan teknologi pembelajaran dalam proses belajar - mengajar ilmu pengetahuan sosial. Pidato pengukuhan Guru besar di depan rapat senat terbuka, di Universitas Negeri Yogyakarta. 